\title{
New Aspects in European Accounting Regulation of Micro-entities
}

\section{Dear readers,}

this year, become important one, from the perspective of European accounting and financial reporting regulation of micro-entities. Microentities, a sub-group of micro-enterprises, have been introduced to cover companies with lower size criteria for balance sheet total and net turnover than those laid down for micro-enterprises. New directive 2012/6/EU of the European Parliament and of the Council of 14 March 2012 on reporting of micro-entities that has been developed and proposed by the European Commission was based on different research studies, particularly International Federation of Accountants.

The reporting needs of micro-entities are fundamentally different from those of larger companies. Although the Directives $\left(4^{\text {th }}\right.$ Directive 78/660/EEC and $7^{\text {th }}$ Directive 83/349/EEC) contain exemptions for small and medium-sized companies from certain obligations, overall, these were often still subject to the same rules as larger companies. Complexity and wide scope of the Accounting Directives' requirements have led to extensive costs which divert resources from the core business activities of small companies. Consequently, the economic burden on the smallest enterprises was disproportional as compared to the larger enterprises. Therefore, it should be possible to exempt micro-entities from certain obligations that may impose on them an unnecessarily onerous administrative burden. However, micro-entities should still be subject to any national obligation to keep records showing their business transactions and financial position.

The Accounting Directives as well as International Financial Reporting Standards were developed with the investor protection as an overarching objective. Thus they contain numerous measures to ensure that minority stockholders have proper information, that the valuation methods are appropriate and give a true and fair view of the company, that all subsidiaries are properly consolidated, and finally that independent auditor presents opinion on the quality of the reports. It has been a consensus for the last decades that such investor oriented financial statement will also serve most of the needs of other stakeholders in a 
satisfactory manner. Therefore, the Directives have not introduced specific accounting rules for SMEs or micro-entities or even microentities, but instead, they contain certain opt outs from the rules designed for bigger companies.

Generally, the stakeholders of very small companies are limited and differ significantly from those of big corporations. These companies are effectively owner managed and statutory financial statements do not have significant relevance for the owners in reviewing the company's performance. Moreover, investors into these entities are often limited in number, frequently directly involved in running of the company and with direct insight into company's accounts. The source of financing is not stock market but own resources, credit from banks or other financial institutions. Thus the main users are banks and tax authorities and other small companies, not an anonymous investor. It is common that especially tax authorities have special reporting needs known as tax accounting which differs significantly from financial reporting. Also banks demand more information that will allow them to assess recoverable amount of assets in case of bankruptcy and thus are not interested in sophisticated accrual accounting vehicles such as deferred tax or goodwill. Moreover banks and tax authorities have direct contacts (as opposed to anonymous investor) with small companies and often demand tailor made information. Consequently, the users of micro accounts are more likely to demand information on recoverable amount of assets (banks) or taxable profit (tax authorities) rather than various disclosures or sophisticated accrual accounting information. Therefore, companies that have to produce essentially investor oriented accounts devote time and money to accounting techniques that use no purpose and only satisfy legal requirements. They often need help from external accountants to prepare these accounts as the techniques are often complex and not the core competence of the managers of micro business. For the same reason the statutory accounts provide seldom useful information for the managers to utilize.

It is appropriate that these companies will be able to follow the Directives' accounting rules as transposed by the Member States on a voluntary basis as well as have their accounts audited if necessary. Proper bookkeeping is essential for the management of any company. Member States have bookkeeping requirements for companies and these will continue to be in place. The Commission proposal will enable Member States to align their accounting requirements to the needs of the users of 
micro-entities' accounts, mainly creditors and tax authorities. The financial reporting needs of micro-entities are rather basic and the statutory accounts are not the only source of information for their stakeholders.

Despite the fact that publication of annual accounts can be burdensome for micro-entities, micro-entities should still be subject to any national obligation to keep records showing their business transactions and financial position. On the other hand Member States should be permitted to exempt micro-entities from a general publication requirement. The only obligation of micro-entity is that the balance sheet information is transmitted to the business register, so that a copy should be obtainable upon application.

An exemption from the Directives' requirements will result in cost savings for the micro-entities including their external accounting and audit costs. The aim of the Directive on micro-entities is to enable Member States to create a simple financial reporting environment for micro-entities. A report on the situation of micro-entities taking account in particular of the situation at national level regarding the number of companies covered by the size criteria and the reduction of administrative burdens resulting from the exemption from the publication requirement should be submit to the European Parliament, the Council and the European Economic and Social Committee by the Commission in 2017.

doc. Ing. Marcela ŽÁROVÁ, CSc.

Vice-dean for Foreign Relations

Faculty of Finance and Accounting, University of Economics, Prague 